\title{
The Comparative Advantage of Crude Oil in the Top 10 Oil- Producing Countries
}

\author{
Ph.D. Candidate Osama Elsalih (Eastern Mediterranean University, TR of Northern Cyprus) \\ Assoc. Prof. Dr. Kamil Sertoğlu (Eastern Mediterranean University, TR of Northern Cyprus) \\ Prof. Dr. Mustafa Besim (Eastern Mediterranean University, TR of Northern Cyprus) \\ Asst. Prof. Dr. Abdelhakim Embaya (Sabratha University, Libya)
}

\begin{abstract}
This paper investigates the comparative advantage of crude oil in the top 10 oil-producing countries over the period 1990-2016 through computing the Normalized Revealed Comparative Advantage (NRCA) index and further examines the determinants of this advantage using panel estimation technique. The results of the NRCA index showed that not all the top10 oil-producing countries have a comparative advantage in crude oil production during the study period. Countries like Iran, Iraq, Kuwait, Russia, Saudi, and UAE are found to have a comparative advantage in producing crude oil, while countries like Brazil, China, and the USA have no comparative advantage in producing crude oil. For Canada, its comparative advantage is only revealed just between 2006 and 2016 . The result of the Panel ARDL suggested that in the long run, crude oil price (COP) and daily average of crude oil production (DAP) are found to be positive and significantly related to NRCA, whereas proven reserve (PR) and domestic demand for oil (DDO) are negative and significantly related to NRCA. In the short run, COP, DAP, and DDO have the same effect as in the long run and significantly related to NRCA, while PR is statistically insignificant. Finally, a bidirectional Granger-causality is detected between the variables except for the PR and NRCA where a unidirectional causality runs from PR to NRCA.
\end{abstract}

\section{Introduction}

The global efforts to find clean and efficient alternative sources of energy started many decades ago. However, oil still remains the main source of energy with the highest share of consumed energy source compared to the other sources. Figure (1) shows that, despite the decline in the share of oil in the world's energy consumption, oil consumption is the highest with $39 \%$ in 1996 . This decreases to $36 \%$ in 2006 and $34 \%$ in 2016 . Thus, due to the importance of oil as a non-renewable energy source produced in around 100 countries (EIA, 2017) and utilizes all over the world, the competition in the world's oil market is raged as to whether to maximize profits or to secure the supply of energy sources. According to the statistics in Table (1), the top 10 oil-producing countries produce around 63 million barrels of crude oil per day and consume around 48 million barrels per day, with the USA and China as the biggest consumers of crude oil, respectively consume around 7 and 8 million barrels more than their native daily production in 2016 .
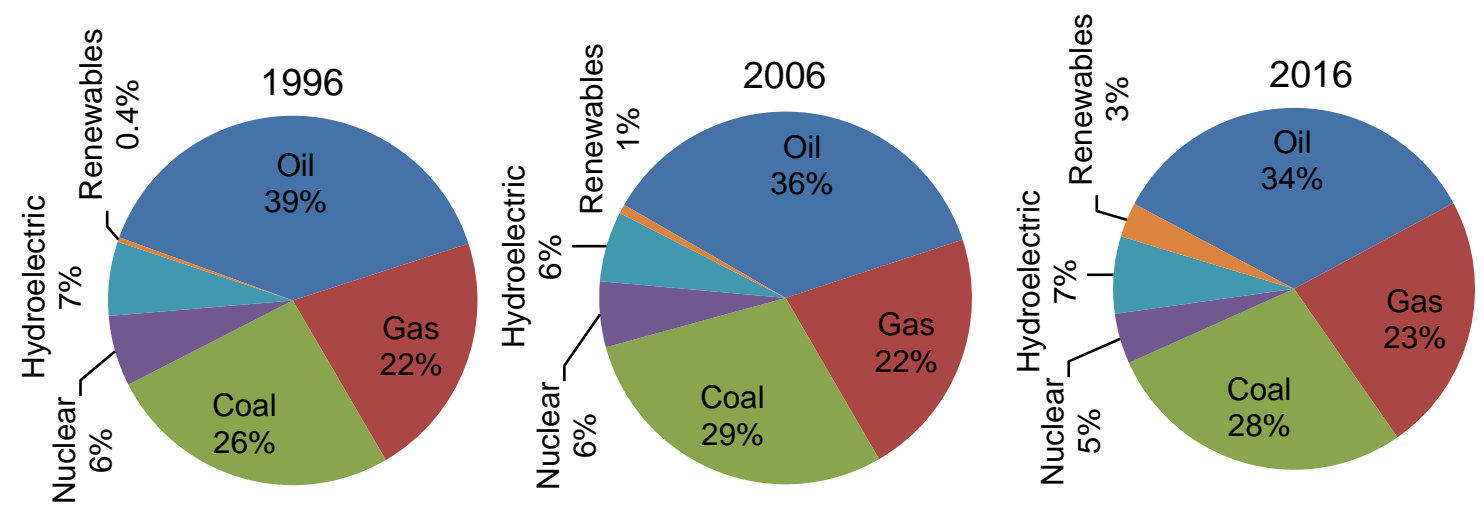

Figure 1. Energy Consumption by Fuel in 1996, 2006 and 2016 


\begin{tabular}{cccc}
\hline Production Rank & Country & $\begin{array}{c}\text { Production } \\
1000 \mathrm{~b} / \mathrm{d}\end{array}$ & $\begin{array}{c}\text { Consumption } \\
1000 \mathrm{~b} / \mathrm{d}\end{array}$ \\
\hline 1 & Saudi & $12,401.80$ & $3,938.60$ \\
2 & US & $12,365.80$ & $19,687.20$ \\
3 & Russia & $11,269.40$ & $3,193.20$ \\
4 & Iran & $4,602.40$ & $1,722.40$ \\
5 & Canada & $4,470.20$ & $2,400.60$ \\
6 & Iraq & $4,422.90$ & 758.00 \\
7 & UAE & $4,019.90$ & $1,002.60$ \\
8 & China & $3,999.20$ & $12,301.70$ \\
9 & Kuwait & $3,145.10$ & 452.80 \\
10 & Brazil & $2,607.80$ & $3,012.70$ \\
Total of the Top 10 countries & $63,304.30$ & $48,470.00$ \\
\hline
\end{tabular}

Table 1. Top 10 Oil-Producing Countries, Production and Consumption in 2016

In the context of international trade, the classical and neoclassical international trade theories argue that a country with a comparative advantage in producing specific commodity can export this commodity to another country produces the same commodity as long as the opportunity cost in the first country is lower than in the other country. However, it has been difficult to apply such a framework in an empirical analysis to measure the comparative advantage (Sanidas and Shin, 2010), until the time when Balassa (1965) proposed the first and the most widely used revealed comparative advantage (RCA) index. This index is based on the idea that the comparative advantage could be "revealed" through analyzing trade patterns of the specific country using post-trade variables. Later on, the Balassa index (BRCA) was revised and modified to several indices so as to address its shortcomings and develop alternative indices. Thus, the latest index in this scope is the Normalized Revealed Comparative Advantage index (NRCA) introduced by Yu et al., (2009). This index is developed to overcome the shortcomings of the other RCA indices and to provide a reliable and systematic tool for assessing the comparative advantage over space and time (Yu et al., 2009).

It is well established in the existed literature of the comparative advantage that the RCA indices could just identify whether a country has a comparative advantage through the consistency between production intensity and the export structures of a specific economy but are not able to identify the reason behind the change in comparative advantage (Batra and Khan, 2005). Therefore several empirical studies investigated the comparative advantage of a variety of economic activities using one of RCA indices with a different method of econometrics. For instance, Yeats (1985) used the BRCA index for the industrial sector. Similarly, Abidin and Loke (2008), Fertö and Hubbard (2003) and Bojnec (2001) used the BRCA index for agricultural and food agricultural sector; Nath et al., (2015), Seyoum (2007) and Langhammer (2004) for service sector; Chi and Kilduff (2006) and Havrila and Gunawardana (2003) for textile and clothing sector. Moreover, Ahrend, (2006), Utkulu and Seymen (2004) and Valentine and Krasnik (2000) used BRCA for the whole SITC-3 commodity classifications. More recently, the relatively new NRCA index was used to assess the comparative advantage in agriculture and some specific crops and life stock (see Hoang et al., 2017; Seleka and Kebakile, 2017; Sarker and Ratnasena, 2014; Sharma et al., 2014; Ndayitwayeko et al., 2014), also this index was used to measure the comparative advantage of cheese production (see Balogh and Jambor, 2017), and tourism and travel service sector (see Toit, et al., 2010; Fourie, 2009).

Following the existing literature on the comparative advantage, and recognizing the importance of oil as the main source of energy globally, the objectives of this paper are (a) to assess the comparative advantage of producing crude oil in the top10 oil-producing countries (Brazil, Canada, China, Iran, Iraq, Kuwait, Russia, Saudi, UAE, USA) over the period of 27 years (1990-2016); and (b) to investigate the determinants of the comparative advantage of producing crude oil in the sampled countries, in order to answer the following two crucial research questions:

Do all oil-producing countries have a comparative advantage in crude oil production?

What are the main factors that determine the comparative advantage of crude oil production?

The paper is organized as follows: Section two is methodology and data. Section three discusses the results and section four concludes the paper.

\section{Methodology and Data}

In this paper, we use NRCA index to quantitatively measure the comparative advantage of crude oil production in the top 10 oil-producing countries. We then employ a panel data technique through a Panel Autoregressive Distributive Lag (ARDL), proposed by Pesaran et al. (1999) to estimate the relationship between the comparative advantage (NRCA index) and four explanatory variables, which are crude oil price (COP), proven reserve (PR), daily average of crude oil production (DAP) and domestic demand for crude oil (DDO). These variables are selected so as to capture the effect of the exogenous shocks in oil prices, the endowed natural resource and the 
domestic supply and demand for crude oil on the comparative advantage of crude oil production. In terms of data, this paper mainly relies on secondary data, collected from the United Nation Com trade database, and the Organization of the Petroleum Exporting Countries (OPEC).

\subsection{Measuring revealed comparative advantages (RCA)}

The NRCA is a relatively new index possesses a group of favorable properties that make this index a superior, and most successful to overcomes the shortcomings of the alternative RCA indices, except the properties of normality of error terms assumption (Bebek, 2017; Sanidas and Shin, 2010). The NRCA index has a constant mean, symmetry, and distributed between -0.25 and +0.25 , which are the required properties for time-series econometric studies. Thus, the NRCA for a country $\mathrm{i}$ in commodity $\mathrm{j}$ can be calculated as follow:

$$
\operatorname{NRCA}_{j}^{i}=\frac{\Delta E_{j}^{i}}{E_{w}}=\frac{E_{j}^{i}}{E_{w}}-\frac{E_{w j} \cdot E^{i}}{E_{w} \cdot E_{w}}
$$

Where $E_{j}^{i}$ refers to the export of country $i$ from commodity $j$ which is crude oil in this study; $E^{i}$ is the total exports of the country $i$; $E_{w j}$ is the world's total export from the commodity $j ; E_{w}$ is the world's total export. Basically, the method of the NRCA index gauges the degree of deviation of actual $E_{j}^{i}$ from the neutral point of its comparative advantage $\widehat{E}_{j}^{i}$ in terms of its relative scale with respect to the world's export of the same commodity, where the neutral point of the comparative advantage $\widehat{E}_{j}^{i}$ of $E_{j}^{i}$ can be expressed as $\widehat{E}_{j}^{i}=\frac{E^{i} \cdot E_{j}}{E}$. Thus, a country can enjoy a comparative advantage in producing and exporting a commodity $\mathrm{j}$ when NRCA $>0$, this means the country's export from the commodity $\left(E_{j}^{i}\right)$ is greater than the natural point of its comparative advantage $\left(\widehat{E}_{j}^{i}\right)$. On the other hand, in case of where NRCA $<0$, the country has no comparative advantage, i.e. the country's export from the commodity $\left(E_{j}^{i}\right)$ is less than the natural point of its comparative advantage, ( $\left.\widehat{E}_{j}^{i}\right)$ (Yu et al., 2009).

\subsection{Panel Estimation}

As mentioned earlier, the RCA indices are unable to identify the sources of the comparative advantage. For this reason, several studies have used the comparative advantage indices with a variety of econometric models to identify the key drivers of the comparative advantage. Therefore, in this study, we employ a panel data technique to estimate the relationship between the comparative advantage and the explanatory variables. In order to employ a panel data framework, we need to address two main issues to determine whether to follow first- or secondgeneration panel estimation (Breitung and Pesaran, 2008). Thus, Breusch and Pagan (1980) test, Pesaran (2004) $\mathrm{CD}$ test and Pesaran and Ullah and Yamagata (2008) tests are used to investigate the presence of the cross-sectional dependency (CD) in the panel. Then Swamy (1970) test is employed to detect whether the slope in the panel data is homogeneous or not. Regarding the Unit root, we explored Pesaran CIPS (2007) unit root test for heterogeneous panels. This test augments the typical Augmented Dickey-Fuller test (ADF) with an average of the cross-section of the lagged level and the first difference of each time series. To detect the existence of the long-run cointegration relationship in the panel, we used Durbin-Hausman panel cointegration test developed by Westerlund (2008). This test is superior in panel data in the presence of heterogeneity, cross-section dependency, absence of stationarity, and mixed order of cointegration. This test is designed to exam the null hypothesis of no cointegration in group and panel at the same time using two subtests $-\mathrm{DH}_{\mathrm{g}}$ which denotes a test for group mean statistic and $\mathrm{DH}_{\mathrm{p}} \mathrm{which}$ denotes a test for panel statistic (Westerlund, 2008).

For estimating the coefficients of the relationship between comparative advantage and the explanatory variables as mentioned, we employed panel ARDL for large $\mathrm{T}$ and $\mathrm{N}$ panels. This mode is used in econometrics research due to its enviable advantages compared to other models that account for endogeneity, separately provides longrun and short-run coefficients as well as applicability for mixed order of integrated variables, i.e. whether I(0) or I(1) or partially integrated (Pesaran, et al. 1999). The Panel ARDL as an advanced version of the ARDL model works via three different methods, namely; Pooled Mean Group (PMG), Mean Group (MG), and Dynamic Fixed Effect (DFE). Specifically, this model is an intermediate procedure model, where the PMG works between MG and DFE functions. In more details, while the MG estimates both short-run and long-run coefficients and allows for heterogeneity, the DFE restricts homogeneity in both short run and long run, but PMG allows for heterogeneity in the short run and restricts homogeneity in the long run (Pesaran et al., 1999). The specification of the Panel ARDL model is given by the following equation:

$$
\mathrm{y}_{\mathrm{it}}=\sum_{\mathrm{j}=1}^{\mathrm{p}} \lambda_{\mathrm{ij}} \mathrm{y}_{\mathrm{i}, \mathrm{t}-\mathrm{j}}+\sum_{\mathrm{j}=0}^{\mathrm{q}} \delta_{\mathrm{ij}}^{\prime} \mathrm{x}_{\mathrm{i}, \mathrm{t}-\mathrm{j}}+\mu_{\mathrm{i}}+\varepsilon_{\mathrm{it}}
$$

Where $t$ is the time period $t=1,2, \ldots, T$; $i$ is the number of the group (countries) $i=1,2, \ldots, N ; y_{i t}$ is the dependent variable of the group $\mathrm{i}$ in time period $\mathrm{t}$; $\mathrm{x}_{\mathrm{it}}$ is the independent variables for group $\mathrm{i}$ in time $\mathrm{t} ; \delta_{\mathrm{ij}}$ is the coefficient of the independent variables; $\lambda_{\mathrm{ij}}$ is the coefficient of the lagged dependent variable $\mathrm{y}_{\mathrm{i}, \mathrm{t}-\mathrm{j}}$. Thus, specifying this model based on equation (2) for the panel yields:

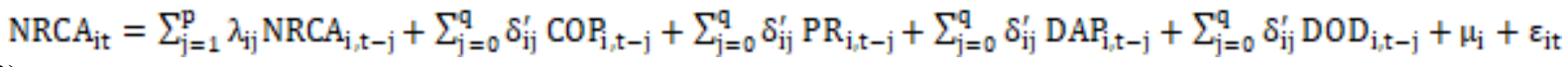


Finally, Dumitrescu and Hurlin in (2012) panel Granger non-causality test is used to understand the direction of the relationship between the variables. The null hypothesis for this test is that the independent variable does not Granger-cause the dependent variable.

\section{Empirical Results and Discussion}

\subsection{Measuring the NRCA for oil production}

Following the calculated scores of the NRCA of producing crude oil in the sampled countries in appendix (A), we can conclude that not all the top 10 oil-producing countries have a comparative advantage in producing crude oil. While Iran, Iraq, Kuwait, Russia, Saudi, UAE have a comparative advantage in crude oil production, on the other hand, the USA, China and Brazil have no comparative advantage in this industry. Whereas Canada's comparative advantage is revealed just between 2006 and 2016. Nonetheless, discussing these results in light of the Heckscher Ohlin (H-O) trade theory implies that, as oil production industry is a capital-intensive industry (Westney, 2011), our results for Canada Iran, Iraq, Kuwait, Russia, Saudi, UAE as capital-abundant countries (Bolbol and Young, 1992), therefore, support the H-O theory. However, our result for Brazil as a capital-abundant country (Muriel and Terra, 2009) and the USA as capital-abundant country as well (Krugman, 2008) does not support this theory.

\subsection{Panels estimation and empirical results}

Based on the results of the diagnostic tests, which are available to request, the panel data is facing the problems of cross-sectional dependence and heterogeneity of slope parameters. These problems mean that following the second-generation panel technique guarantees better and robust results. Furthermore, the result of CIPS panel unit root indicates a different order of variables cointegration, where the COP variable is stationary at level, I(0) and all the remaining variables are stationary at first difference I(1). Moreover, the results of the Durbin-Hausman cointegration test as shown in Table 2, presents evidence that the null hypothesis of no cointegration is perhaps rejected both in the panel and in the groups at 5\% level of significance when the test is carried out with constant and constant and trend. Therefore, we can conclude the existence of a valid long-run relationship between the variables captured in this study. Hence, we proceed to estimate our model.

\begin{tabular}{lcccccc}
\hline & \multicolumn{2}{c}{ Non } & \multicolumn{2}{c}{ Constant } & \multicolumn{2}{c}{ Constant \& trend } \\
\cline { 2 - 7 } & Statistic & P-value & Statistic & P-value & Statistic & P-value \\
$\mathrm{DHg}$ & -0.094 & 0.463 & -2.276 & 0.011 & -2.119 & 0.017 \\
$\mathrm{DHp}$ & -1.307 & 0.096 & -1.801 & 0.036 & -1.795 & 0.036 \\
\hline
\end{tabular}

Table 2. Durbin-Hausman Panel Cointegration Test

After estimating the coefficients of the long-run and short-run relationship among the variables investigated via PMG and MG methods of the Panel ARDL (1, 1, 1, 1, 1) model, we applied Hausman (1978) test for pairwise comparison between the MG and PMG estimations to decide which method is the most preferable and as such provide consistent and efficient results by testing the null hypothesis of homogeneity restrictions. The result of the Hausman test in the lower part of Table 3 shows that the null hypothesis cannot be rejected. This suggests that the $\mathrm{PMG}$ estimation is preferable to the MG estimation.

\begin{tabular}{|c|c|c|c|c|c|c|}
\hline & \multicolumn{3}{|c|}{ PMG } & \multicolumn{3}{|c|}{ MG } \\
\hline & Coefficients & $\mathrm{SE}$ & $\mathrm{P}>\mathrm{Z}$ & Coefficients & $\mathrm{SE}$ & $\mathrm{P}>\mathrm{Z}$ \\
\hline Speed of adjustment & -0.175 & 0.087 & 0.045 & -0.571 & 0.076 & 0.000 \\
\hline \multicolumn{7}{|l|}{ Long Run Coefficients } \\
\hline $\mathrm{COP}$ & 0.466 & 0.097 & 0.000 & 0.218 & 0.353 & 0.536 \\
\hline PR & -1.351 & 0.311 & 0.000 & -0.469 & 0.290 & 0.106 \\
\hline DAP & 1.699 & 0.275 & 0.000 & 0.675 & 0.313 & 0.031 \\
\hline DDO & -0.414 & 0.198 & 0.037 & -0.12 & 0.390 & 0.757 \\
\hline \multicolumn{7}{|l|}{ Short Run Coefficients } \\
\hline$\Delta \mathrm{COP}$ & 0.48 & 0.195 & 0.014 & 0.489 & 0.192 & 0.011 \\
\hline$\Delta \mathrm{PR}$ & -0.281 & 0.174 & 0.106 & -0.255 & 0.148 & 0.086 \\
\hline$\triangle \mathrm{DAP}$ & 0.816 & 0.417 & 0.050 & 0.799 & 0.380 & 0.036 \\
\hline$\Delta \mathrm{DDO}$ & -0.274 & 0.165 & 0.097 & -0.061 & 0.245 & 0.801 \\
\hline Constant & -0.010 & 0.040 & 0.795 & -0.038 & 0.032 & 0.242 \\
\hline \multicolumn{7}{|l|}{ Hausman test MG vs PMG } \\
\hline $\operatorname{chi} 2(10)$ & 13.79 & & & & & \\
\hline Prob>chi 2 & 0.1827 & & & & & \\
\hline
\end{tabular}

Table 3. Panel PMG and MG Estimation \& Hausman Test 
Regarding the results of the panel ARDL, based on the two estimation methods, there is evidence that the speed of adjustment coefficients are all negative and highly significant at 5\% and 1\% level of significance for PMG and MG respectively. This confirms the long-run relationship obtained through the panel cointegration test in Table 2.

Turning to the coefficients of crude oil price (COP) in Table 3, the estimation of the PMG show that, the effect of the COP on the comparative advantage of crude oil in the top 10 oil-producing countries is positive and statistically significant at $1 \%$ and $5 \%$ in both long run and short run respectively. This established relationship between COP and comparative advantage mainly reflects the relationship between COP, production, and exports of crude oil since the NRCA index is calculated by post-trade data. The implication for this result is that as the COP increases, it will lead to more oil production and exportation, which revealed the comparative advantage of the country. However, according to Cologni and Manera, (2014), oil-producing countries are characterized by different responses to exogenous shocks in world oil demand and oil prices. Conventionally, such relationships always investigate in the form of comparison between the reactions of OPEC and non-OPEC countries. Therefore, our result is in support of the positive relationship between the COP and crude oil production in OPEC countries based on the findings of Ratti and Vespignani (2015); Brémond, et al, (2012); Kaufmann, et al. (2004). In addition, this finding is congenial to Ramcharran (2002) who found a positive relationship between COP and crude oil production in non-OPEC countries. Conversely, our result is not consistent with a negative relationship between COP and crude oil production found by Ramcharran (2002) in OPEC countries, and in non-OPEC countries found by Ratti and Vespignani (2015).

The proven reserve variable (PR) represents the endowed natural resource of the crude oil that is already discovered and available for production. Basically, according to Harold Hotelling (1931), the price of depletable (non-renewable) natural resource tends to be higher than marginal cost or equal to the interest rate, in order to compensate stock resources exhausted, even in a perfectly competitive market. This is known as Hotelling rent or scarcity rent (Krautkraemer, 1998; Hamilton, 2008). Accordingly, the scarcity of crude oil as a depletable resource causes its price to rise (Frankel, 2010). Therefore, the established negative relationship between PR and the comparative advantage in this study is apparently due to the growth of PR, i.e. crude oil abundance, which in turn leads to growth in the supply of crude oil. Consequentially, this will lead to an inverse relationship between PR and comparative advantage. Our result further suggests that PR has a negative and significant relationship with the comparative advantage in the long-term based on the PMG estimation, while it is negative but statistically insignificant in the short run. This result agrees with the thought that natural resource is one of the determinants of comparative advantage, in addition to a number of socio-economic factors (Yeats, 1985). However, this result is inconsistent with the findings documented by Heller (1976); Gunton (2003); Svaleryd and Vlachos (2005); Fourie (2009); Toit, et al. (2010); Hoang, et al. (2017); Balogh and Jambor (2017) that natural resources are positively related to comparative advantage.

The daily average of crude oil production variable (DAP), which expresses the capacity of oil production per day, has a positive and statistically significant effect on the comparative advantage in both the long and short run. These results align with the finding of Yue and Hua (2002) that the rapid growth of domestic production capacity stimulates the value of export.

Lastly, the domestic demand for crude oil (DDO) has a negative and statistically significant effect on the comparative advantage in both the long run and short run. These results are in support of the idea documented by Bowen (1983) that the comparative advantage is a net trade concept where he proposed two alternative RCA indices. One of these indices is the production intensity index based on the relationship between domestic production and consumption, and net trade intensity index (Vollrath, 1991). This relationship has also been proved by Sharma et al., (2014) and Seleka and Kebakile, (2017). The implication for this relationship can be traceable to the fact that as the domestic demand for crude oil increases, it will lead to more crude oil production and less exportation. This may also lead to importing crude oil in some cases to cover the increasing domestic demand. The implication for this result can be seen clearly in the case of the USA and China as the biggest oil consumers. Although these countries are among the top 10 oil producers (see Table 1), but they have no comparative advantage in crude oil.

In terms of panel Granger non-causality test, the results shown in Table 4 present a bidirectional (two-way) causal relationship between all variables used except the causal relationship between PR and NRCA, which indicates a unidirectional (one-way) causality running from PR to NRCA. These results, therefore, support the earlier results of the panel ARDL model which show that the four dependent variables have a significant relationship with the comparative advantage. 


\begin{tabular}{ccc}
\hline Null Hypothesis & Statistic & P-Value \\
\hline COP does not Granger-cause NRCA & 5.8 & 0.000 \\
NRCA does not Granger-cause COP & 1.98 & 0.047 \\
PR does not Granger-cause NRCA & 8.82 & 0.000 \\
NRCA does not Granger-cause PR & 0.35 & 0.719 \\
ADP does not Granger-cause NRCA & 4.52 & 0.000 \\
NRCA does not Granger-cause ADP & 15.92 & 0.000 \\
NOD does not Granger-cause NRCA & 9.34 & 0.000 \\
NRCA does not Granger-cause NOD & 3.48 & 0.000 \\
\hline
\end{tabular}

Table 4. Granger Causality Test

\section{Conclusion}

This paper aimed to explore the comparative advantage of crude oil in the top 10 oil-producing countries and investigating the determinants of this advantage. To achieve these objectives, the NRCA index was used to compute the comparative advantage of crude oil and the panel data technique employed to estimate the relationship between the comparative advantage embodied in the NRCA index and four explanatory variables (COP, PR, DAP, and DDO). Consequently, the sample and the methodology used allowed us to derive meaningful and robust results. These results revealed that not all the top 10 crude oil-producing countries have a comparative advantage in crude oil production. In addition, the four explanatory variables (COP, PR, DAP, and DDO) have significant relationships with the comparative advantage in both long run and short run. Hence the paper concludes that these variables are among the main determinants of the comparative advantage of crude oil production in the sampled countries.

\section{References}

- $\quad$ Abidin, M. Z., \& Loke, W. H. (2008). Revealed comparative advantage of Malaysian exports: The case for changing export composition. Asian Economic Papers, 7(3), 130-147.

- Ahrend, R. (2006). Russian industrial restructuring: Trends in productivity, competitiveness and comparative advantage. Post-Communist Economies, 18(3), 277-295.

- Balassa, B. (1965). Trade liberalisation and "revealed" comparative advantage 1. The Manchester school, 33(2), 99-123.

- Balogh, J. M., \& Jámbor, A. (2017). Determinants of revealed comparative advantages: The case of cheese trade in the European Union. Acta Alimentaria, 46(3), 305-311.

- $\quad$ Batra, A., \& Khan, Z. (2005). Revealed comparative advantage: An analysis for India and China (No. 168). Working paper.

- Bebek, U.G. (2017). RCA: Choosing the Right Measure. Department of Economics, University of Birmingham.

- Bojnec, $\breve{S}$. (2001). Trade and revealed comparative advantage measures: regional and central and east European agricultural trade. Eastern European Economics, 39(2), 72-98.

- Bolbol, A. A., \& Young, L. (1992). Development with limited and unlimited supplies of capital. The Manchester School of Economic \& Social Studies, 60(3), 307-316.

- Breitung, J., \& Pesaran, M. H. (2008). Unit roots and cointegration in panels. In The econometrics of panel data (pp. 279-322). Springer, Berlin, Heidelberg.

- Brémond, V., Hache, E., \& Mignon, V. (2012). Does OPEC still exist as a cartel? An empirical investigation. Energy Economics, 34(1), 125-131.

- Chi, T., \& Kilduff, P. (2006). An assessment of trends in China's comparative advantages in textile machinery, man-made fibers, textiles and apparel. Journal of the Textile Institute, 97(2), 173-191.

- Cologni, A., \& Manera, M. (2014). On the economic determinants of oil production: Theoretical analysis and empirical evidence for small exporting countries. Energy Economics, 44, 68-79.

- Du Toit, L., Fourie, J., \& Trew, D. (2010). The sources of comparative advantage in tourism. Stellenbosch Economic working papers, 01/10.

- EIA (2017) U.S. Energy Information Administration. Where our oil comes from, https://www.eia.gov/energyexplained/index.php?page=oil_where.

- $\quad$ Fertö, I., \& Hubbard, L. J. (2003). Revealed comparative advantage and competitiveness in Hungarian agrifood sectors. World Economy, 26(2), 247-259.

- Frankel, J. A. (2010). The natural resource curse: a survey (No. w15836). National Bureau of Economic Research. 
- Gunton, T. (2003). Natural resources and regional development: An assessment of dependency and comparative advantage paradigms. Economic Geography, 79(1), 67-94.

- Hamilton, J. D. (2008). Understanding crude oil prices (No. w14492). National Bureau of Economic Research.

- Havrila, I., \& Gunawardana, P. (2003). Analysing comparative advantage and competitiveness: an application to Australia's textile and clothing industries. Australian Economic Papers, 42(1), 103-117.

- Hoang, V. V., Tran, K. T., Tu, B. V., Nguyen, V. N., \& Nguyen, A. Q. (2017). Agricultural Competitiveness of Vietnam by the RCA and the NRCA Indices, and Consistency of Competitiveness Indices. AGRIS on-line Papers in Economics and Informatics, 9(665-2018-3598).

- Kaufmann, R. K., Dees, S., Karadeloglou, P., \& Sanchez, M. (2004). Does OPEC matter? An econometric analysis of oil prices. The Energy Journal, 67-90.

- Krautkraemer, J. A. (1998). Nonrenewable resource scarcity. Journal of Economic literature, 36(4), 20652107.

- Krugman, P. R. (2008). International economics: Theory and policy, 8/E. Pearson Education India.

- Langhammer, R. J. (2004). Revealed comparative advantages in the services trade of the United States, the European Union and Japan: what do they tell us. J. World Investment \& Trade, 5, 887.

- Muriel, B., \& Terra, C. (2009). Sources of comparative advantages in Brazil. Review of Development Economics, 13(1), 15-27.

- Nath, H. K., Liu, L., \& Tochkov, K. (2015). Comparative advantages in US bilateral services trade with China and India. Journal of Asian Economics, 38, 79-92.

- $\quad$ Ndayitwayeko, W. M., Odhiambo, M. O., Korir, M., Nyangweso, P. M., \& Chepng'Eno, W. (2014). Comparative advantage of the eastern and central Africa in the coffee export sector: the case of Burundi. African Crop Science Journal, 22, 987-995.

- $\quad$ Pesaran, M. H., Shin, Y., \& Smith, R. P. (1999). Pooled mean group estimation of dynamic heterogeneous panels. Journal of the American Statistical Association, 94(446), 621-634.

- Ramcharran, H. (2002). Oil production responses to price changes: an empirical application of the competitive model to OPEC and non-OPEC countries. Energy economics, 24(2), 97-106.

- $\quad$ Ratti, R. A., \& Vespignani, J. L. (2015). OPEC and non-OPEC oil production and the global economy. Energy Economics, 50, 364-378.

- Sanidas, E., \& Shin, Y. (2010, June). Comparison of revealed comparative advantage indices with application to trade tendencies of East Asian countries. In 9th Korea and the World Economy Conference, Incheon.

- $\quad$ Sarker, R., \& Ratnasena, S. (2014). Revealed Comparative Advantage and Half-a-Century Competitiveness of Canadian Agriculture: A Case Study of Wheat, Beef, and Pork Sectors. Canadian Journal of Agricultural Economics/Revue canadienne d'agroeconomie, 62(4), 519-544.

- Seleka, T. B., \& Kebakile, P. G. (2017). Export Competitiveness of Botswana's Beef Industry. The International Trade Journal, 31(1), 76-101.

- Seyoum, B. (2007). Revealed comparative advantage and competitiveness in services: A study with special emphasis on developing countries. Journal of Economic Studies, 34(5), 376-388.

- Sharma, P. U. R. U. S. H. O. T. T. A. M., Patel, R. M., \& Srivastava, S. K. (2014). Comparative advantage of Indian soymeal vis-à-vis major exporters. Soybean Research, 12(1), 129-143.

- Svaleryd, H., \& Vlachos, J. (2005). Financial markets, the pattern of industrial specialization and comparative advantage: Evidence from OECD countries. European Economic Review, 49(1), 113-144.

- Utkulu, U., \& Seymen, D. (2004, September). Revealed Comparative Advantage and Competitiveness: Evidence for Turkey vis-à-vis the EU/15. In European trade study group 6th annual conference, ETSG (pp. 1-26).

- Valentine, N., \& Krasnik, G. (2000). SADC trade with the rest of the world: Winning export sectors and revealed comparative advantage ratios. South African journal of economics, 68(2), 114-124.

- Vollrath, T. L. (1991). A theoretical evaluation of alternative trade intensity measures of revealed comparative advantage. Weltwirtschaftliches Archiv, 127(2), 265-280.

- Westerlund, J. (2008). Panel cointegration tests of the Fisher effect. Journal of Applied Econometrics, 23(2), 193-233.

- Westney, R. (2011). Assessing the risk in capital-intensive opportunities. Oil \& Gas Financial Journal. 
- Yeats, A. J. (1985). On the appropriate interpretation of the revealed comparative advantage index: implications of a methodology based on industry sector analysis. Weltwirtschaftliches Archiv, 121(1), 61-73.

- Yu, R., Cai, J., \& Leung, P. (2009). The normalized revealed comparative advantage index. The Annals of Regional Science, 43(1), 267-282.

- Yue, C., \& Hua, P. (2002). Does comparative advantage explains export patterns in China?. China Economic Review, 13(2-3), 276-296.

\section{Citations}

- $\quad$ Figure (1) constructed by the authors using data from British Petroleum (BP) Statistical Review of World Energy (2018).

- Table (1) constructed by the authors using data from British Petroleum (BP) Statistical Review of World Energy (2018)

Appendix A

\begin{tabular}{ccccccccccc}
\hline Year & Brazil & Canada & China & Iran & Iraq & Kuwait & Russia & Saudi & UAE & USA \\
\hline 1990 & -6.4 & -12.1 & -3.5 & 45.1 & 25.8 & 17.1 & 16.9 & 108 & 38.5 & -79.2 \\
1991 & -5.3 & -6.0 & -3.5 & 41.5 & 0.9 & 2.3 & 17.2 & 119.7 & 37.8 & -70.3 \\
1992 & -3.6 & -2.5 & -3.6 & 38.9 & 1.2 & 16.1 & 17.8 & 120.5 & 35.7 & -57.8 \\
1993 & -3.5 & -2.7 & -4.4 & 32.8 & 1.1 & 25.4 & 21.0 & 100.7 & 30.4 & -55.2 \\
1994 & -3.8 & -5.1 & -8.5 & 30.9 & 1.0 & 24.2 & 23.3 & 88.1 & 25.4 & -55.1 \\
1995 & -3.2 & -2.0 & -8.3 & 28.9 & 0.9 & 23.5 & 20.1 & 84.4 & 23.6 & -49.3 \\
1996 & -3.5 & -3.5 & -9.0 & 36 & 1.3 & 26.3 & 20.9 & 100.6 & 26.1 & -58.9 \\
1997 & -3.4 & -3.0 & -10.6 & 27.8 & 8.7 & 24.2 & 20.6 & 95.6 & 25.9 & -57.6 \\
1998 & -1.4 & -1.6 & -8.2 & 18.5 & 9.5 & 15.7 & 13.8 & 60.1 & 19.5 & -39.7 \\
1999 & -1.6 & -6.3 & -14 & 28.1 & 21.3 & 19.4 & 19.1 & 79.0 & 24.9 & -53.4 \\
2000 & -2.6 & -5.3 & -19.8 & 37.4 & 29.2 & 26.8 & 27.6 & 104.3 & 36.5 & -71.7 \\
2001 & -2.1 & -4.9 & -20.1 & 33.0 & 24.2 & 23.1 & 30.2 & 92.0 & 35.0 & -60.9 \\
2002 & -2.3 & -2.9 & -24.8 & 27.7 & 18.6 & 20.7 & 34.4 & 93.7 & 31.4 & -56.9 \\
2003 & -2.6 & -0.5 & -30.2 & 32.5 & 9.5 & 24.0 & 39.6 & 103.4 & 34.2 & -53.3 \\
2004 & -3.6 & 0.3 & -37.8 & 34.8 & 18.3 & 27.5 & 48.6 & 113.8 & 36.7 & -53.5 \\
2005 & -4.5 & -1.9 & -52 & 46.8 & 21.1 & 37.8 & 59.5 & 143.3 & 44.8 & -63.9 \\
2006 & -3.4 & 2.3 & -61.7 & 43.1 & 23.4 & 40.7 & 60.7 & 145 & 48.9 & -67.8 \\
2007 & -2.4 & 5.2 & -65.2 & 44.7 & 26.3 & 39.2 & 63.3 & 135.8 & 43.6 & -63.1 \\
2008 & -2.6 & 14.1 & -78.7 & 50.4 & 36.1 & 46.7 & 68.4 & 157.9 & 50.3 & -71.8 \\
2009 & -1.0 & 12.8 & -65.0 & 40.0 & 29.5 & 36.4 & 58.7 & 119.6 & 44.1 & -57.2 \\
2010 & 0.8 & 14.3 & -76.9 & 42.2 & 31.5 & 37.6 & 65.1 & 129.7 & 38.8 & -62.0 \\
2011 & -0.4 & 16.7 & -90.7 & 56.5 & 41.9 & 48.6 & 70.1 & 159 & 47.2 & -70.5 \\
2012 & -1.0 & 18.4 & -102.1 & 49.4 & 47.2 & 54.2 & 73.5 & 166.9 & 29.4 & -76.5 \\
2013 & -4.0 & 22.1 & -100.1 & 27.1 & 44.3 & 53.0 & 69.9 & 157 & 29.4 & -69.3 \\
2014 & -0.4 & 27.8 & -95.4 & 24.5 & 41.7 & 46.4 & 62.1 & 138.4 & 33.6 & -59.6 \\
2015 & 0.4 & 18.4 & -68.4 & 14.4 & 28.8 & 28.1 & 44.5 & 87.7 & 23.9 & -40.4 \\
2016 & 0.6 & 14.9 & -54.2 & 23.6 & 26.7 & 25.1 & 39.4 & 80.7 & 21.1 & -31.9 \\
\hline & & & & & & & & & & \\
\hline
\end{tabular}

Table 1. NRCA Scores 